\title{
Stage III Malignant Mediastinal Germ Cell Tumor
}

National Cancer Institute

\section{Source}

National Cancer Institute. Stage III Malignant Mediastinal Germ Cell Tumor. NCI

Thesaurus. Code C146851.

Locoregional tumor, regional lymph nodes negative or positive; no distant metastasis; biopsy only or gross residual tumor after primary resection. (WHO Classification of

Tumors of the Lung, Pleura, Thymus and Heart, 2015) 